\title{
A DAUGHTER'S UNSETTLING AUTO/BIOGRAPHY OF COLONIALISM AND UPROOTING: A CONVERSATION WITH ISABELA FIGUEIREDO
}

\author{
Isabel Ferreira Gould \\ University of Notre Dame \\ Translation by Rex P. Nielson \\ Brigham Young University
}

Isabela Figueiredo (Isabel Almeida Santos) was born in Lourenço Marques, Mozambique, in 1963, the daughter of Portuguese settlers who had emigrated from the central-west region of Portugal. After the independence of Mozambique in 1975, her parents sent her to Portugal, both for her safety and so she could continue her education. In the ten years that followed, she lived in the homes of various relatives in Portugal and spent three years boarding at the Nuno Álvares School in Tomar. She graduated with a degree in Modern Languages and Literatures from the Faculdade de Ciências Sociais e Humanas, Universidade Nova de Lisboa, and later obtained a certificate in Women's Studies from the Universidade Aberta. Isabela Figueiredo worked as a journalist for Diário de Notícias between 1989 and 1994, and she has been a high-school Portuguese teacher since 1990. She is the author of Conto é como quem diz (Odivelas: Europress, 1988) and Caderno de Memórias Coloniais (Coimbra: Angelus Novus; $1^{\text {st }}$ edition, November 2009).

Now in multiple editions, Caderno de Memórias Coloniais continues to garner attention from critics and readers, especially returnees from Africa. Caderno is a complex book about Portuguese colonialism and its many participants. It explores, in particular, the various images that a father-figure may assume: a settler who is both beloved and questioned by his daughter, a colonist who believed in the Portuguese civilizing mission, and also - from our contemporary postcolonial perspective - an abject and politically incorrect actor. The book expresses the injustices of so-called 


\section{Isabel Ferreira Gould}

civilizing acts, namely the racism and violence practiced by the Portuguese in Africa. It reveals, through the particular language of colonists themselves (the work to recover this language is one of the book's great merits), the self-serving logic and ideology promoted by the Estado Novo regime. All of this contrasts with the caustic irony of the woman writer who narrates her childhood and revisits her perspectives on her family history and the public history of colonialism.

The delicate and precarious context of Mozambique on the eve of the April Revolution and the tumultuous period before and after the massacres of 7 September 1974 frame the narrative. Within that setting, Caderno offers the story of a foundational relationship: the love of a father and a daughter in a time of upheaval. It is a memorialistic narrative, an autobiography about the transformation of a daughter's feelings, and the biography of a father based on the memory of his daughter. Caderno is a warning against the passage of time, against erasure and the lacunae of memory; it is a wake-up to the father's voice; an opening of eyes after a deep sleep. The book traces a complex cartography of feelings, seeking to answer two central questions: how to love a father without losing sight of his racist acts? How to remember and forgive him without allowing him to escape the critical, postcolonial understanding of his daughter, who is also his heir?

Caderno has raised a polemic regarding the literary representation of Portuguese racism in Africa and in Portugal. The unequal relationships of power and class among Portuguese colonists, that is, the social, economic, and cultural segregation among them, are new territory for interpretation. Many readers and critics have examined colonial violence as a manifestation of the behavior of poor colonists by mapping social class onto a crudely drawn dichotomy between the bad colonists and good colonists, all of which obscures the systematically oppressive nature of colonial rule. The noise generated by the book results from the manner in which it breaks the silence about the other side of colonization to reveal a colonialism in ruins, shaped by 
the differences and tensions among Portuguese colonists and between the Portuguese and the Africans.

The great contribution of this autobiography resides in the language of rupture it employs, in the discourse it utilizes to describe the violence of feelings and the Portuguese contempt for the other, and in the raw manner in which it shows the intimate dimensions of colonialism. The autobiographical writing of Isabela Figueiredo thus becomes an act of culture, an act of unveiling the colonial world. There is a great resonance between this text and the language and ideology that Maria Isabel Barreno, Maria Teresa Horta, and Maria Velho da Costa explored in Novas Cartas Portuguesas (1972) to give shape to women's experience in the patriarchal, repressive society of the Estado Novo. There are similar parallels between Isabela Figueiredo's book and the counter-narrative of war and colonialism offered by Eva Lopo, also in the first person, through the pen of Lídia Jorge in A Costa dos Murmúrios (1988).

Caderno de Memórias Coloniais belongs to the critical production of first-person narratives (fictional and nonfictional) that seek to purge the ruins of the African empire and Portuguese decolonization. It is a daring example of what I call narratives of decantation, that is, texts written in the first person about the memories and perspectives of children that are structured by the tension between a critical vision of colonialism and the need to exalt, for better or for worse, the foundational figures of the narrating subjects' identities. Though the children of empire seek to break free from the ghosts of colonialism (the paternal phantom, above all), these narratives of decantation nonetheless are filled with the love of children for their problematic and controversial progenitors. Isabela Figueiredo's autobiography undoubtedly contributes to the study of individual memory and identity and promotes a deeper understanding of Portuguese colonialism in Africa and national identity in contemporary Portugal.

Isabel Ferreira Gould: How do you write? When do you write? What are the conditions you need to write? 


\section{Isabel Ferreira Gould}

Isabela Figueiredo: I need total silence in order to write. I can jot down ideas in a café, but it's at home that I develop them. I write by funneling into myself, by looking inward. It's tiring, and in a way it reminds me of the process of psychoanalysis. When I'm writing, I prefer no one visit or call. I have to be left in peace. I stop only to feed the dogs and take them out.

IFG: How should your recent book Caderno de Memórias Coloniais be read?

IF: I hope that Caderno is not read as a provocation or a violent demonstration but as a literary construction about the experience of a woman who was once a child during a period of injustice, which she has never been able to understand or accept. It is an autobiography, tout court. I understand that because the narrative is situated in a complex historical period it also constitutes a discourse that is critical of colonialism and postcolonialism, departing at times from the mere story of a daughter who loved a father who disappointed her so many times. But this was not my intention. I only wanted to tell a story and tell it as well as possible from the point of view of narrative quality.

IFG: What role does Caderno fulfill?

IF: It responds to an intense desire to write, on the one hand, and also to the need to reveal a story that had to be told.

IFG: What challenges did you face while writing this book? IF: I have always written for a blog (novomundoperfeito. blogspot.com) and at one point, when it was open for users to comment, I kept expecting someone to appear who would contradict or insult me. I also saw that some things I wrote were stolen and published in racist right-wing forums. This was hard for me to take. I felt that my message was being distorted and used for the exact opposite purposes of what I had intended. But the greater challenge was to get inside myself. Most of these texts were written in the summer of 2008 , and I remember being at home, sweating in front of my computer while it was beautiful outside, because I had 
entered into this funneling of space and time inside me and I couldn't get out for anything else.

IFG: What are the (dis)advantages of narrating the colonial experience from the subjective perspective of a child, that of the (former) colonist's daughter?

IF: As a writer, there is no disadvantage. As a writer, I'm given enormous literary freedom to include, even in the case of an autobiography, a certain subjectivity. Writing Caderno required a great effort to go back in time that forced me to visualize places, people, and even relive emotions. I admit that we see the world subjectively, that we reinterpret it, but I tried to be as faithful as possible to the memory of the girl I was, to what I witnessed. My intent isn't to replace the historians. An advantage of narrating this history from the daughter's subjective perspective lies in the fact of her having been an intervening figure with power over the action. In a way, as a child, I was deprived of voice, and power, and this positioned me in the same margin as the blacks. I was like an aural witness to that world.

IFG: What can a retrospective and subjective point of view of childhood and adolescence tell us about the colonial past? IF: It is retrospective and subjective, but it is not merely a point of view. It is a life-experience. It is my life. What I felt and thought. I closed my eyes in order to return there and reexamine my father's face, his voice, the faces of my father's blacks, the calluses of their hands. I went there in order to bring back, with the greatest degree of authenticity, this past. I have described it with great honesty. The way in which a child lives the reality that surrounds her is not unworthy of attention. It might even be more accurate than that of an adult, because it is less burdened by prejudices and other mental constructions.

IFG: What does the past mean to you?

IF: The past is the thick trunk of the tree we all belong to. The past constructs us, and upon this construction, we build 


\section{Isabel Ferreira Gould}

the present and consider the future. I am the past, and because of this I can yearn for the future.

IFG: How do these colonial memories coexist with postcolonial Portuguese time?

IF: Initially, not very well. Very painfully, because the conscience does not have pity or give peace. It took a long time before I could admit that my father had been a racist like so many others. It took a long time for me to discover how to communicate this and keep his honor intact.

IFG: How does memory function for you? And fiction?

IF: Those who lose their memory stop knowing who they are. Memory is the archive of our emotions, our sense of self. It situates us in the world. As for fiction, I'm not sure. I don't know if you could say that it is something that is explicitly functional. I write because it is how I express what I think and, above all, it is how I organize my ideas and know what I really think about things. It is my way of reliving the past. I also write because I have a lot of ideas, a lot of opinions, and there are few people to hear me. Perhaps my writing is the fruit of my loneliness.

IFG: In what ways are your recollections transformed?

IF: They are transformed primarily in terms of their placement in space and time. There are a series of situations that I see just as they happened, but I have trouble placing them in space or in the exact time. I speak about this confusion in the book at one point.

IFG: In your opinion, what are the roles of forgetting?

IF: Forgetting protects us, in some cases. Most people prefer to forget, and they do this very well. It is important to move on and forget some events, but it is more important to remember. The ideal would be to always remember a lot, with honesty and humility, so that one day it can be forgotten, if necessary. 
IFG: Your book narrates decisive moments as you pass from childhood to adolescence in Mozambique. What does this coming of age mean to you in an empire in ruins?

IF: It marked my life. It shaped me. I have always lived and struggled with these images and memories. On the other hand, they prevented me from completely belonging to a place. Where do I belong? I am a European born in Africa and influenced by these experiences. But I am also an African confined to Europe and prevented from returning to the land where I was born-because the place exists but not exactly the same "land." I have become an exile who speaks Portuguese and loves Portugal, but nevertheless, I don't belong to it completely.

IFG: The book also expresses a great desire, on the part of the child, to discover the colonial world, and at the same time, to be transformed in and by Africa; for example, a desire to allow herself to be stained, colored, by Africa, and a desire to walk barefoot like Africans. Could you comment on this?

IF: I felt deeply African, like other Africans who had black skin. To the great disgust of my mother, I wanted to wear capulanas (sarongs), like the black girls, to walk barefoot like them, to eat what they ate, to sit on the ground as they sat, to live as they lived. I had a tremendous curiosity about this vast black world that surrounded me but that I was forbidden from entering, because I was white, different. I did not feel different. And I was fascinated by the land. I'm referring to the earth, which was red or black or loose yellow sand. I admired the colors and textures of the soil, and I ate it, literally, I savored it. I knew it well. I was not very happy in Africa because I was the daughter of colonists. If I had been born black, I would have been much happier, freer. But, perhaps then I would have never gone to school and never written this book.

IFG: There are those who say that fictional writings are documentaries of a historical period, of a time. Could autobiography be the fiction of a certain time? 


\section{Isabel Ferreira Gould}

IF: Only insofar as there is always subjectivity in the way we view reality. It is possible to find, regarding Africa, narratives that are entirely different than mine. So, the extent of our vision or experience can condition the documentary nature of autobiography.

IFG: Caderno de Memórias Coloniais is a book about the I in relation to an other (the father), and the tension between them. In doing so it presents the autobiography of the I and the biography of the father. Could you comment on the importance of the father's biography made by the daughter?

IF: Curiously, I never wrote thinking that I was also writing the biography of my father. That's something I didn't think about. I wanted to write my autobiography and the rest came in tow. A son or daughter has access to privileged information about the man who was their father. A biography written by children can be dangerous, because love and the duty to honor the father can make the text very one-sided. In my case, I tried to avoid this impartiality. There were moments when it was not easy, but I tried hard to embrace the luxury of being partial.

IFG: Caderno can be equally read as a narrative structured between the desire to purge memories of the colonial experience and the desire to praise and pay homage to the land where you were born and to which you belonged.

IF: Yes, you are correct, it can in fact be read in this way. But it can be read in many ways. It can equally be read as a book of love or of travels. It's also a journey.

IFG: There is in your book a great effort to rebuild the universe and mentality of the colonist. In Caderno, the Portuguese are the "perpetrators," but they are also, in another sense, the poor and the forgotten. What distinguishes Caderno from other works of fiction or other memoirs regarding the Portuguese abroad, specifically regarding the image of the Portuguese colonist?

IF: The other books I'm familiar with about the topic present the Portuguese as the winners, as free lords in a free land, 
living in a kind of Babylonian hanging gardens. And if, on the one hand, this side in fact existed, real life was very different. My father was a man who worked hard in Lourenço Marques. But in spite of this, he was never rich. However, his work allowed him to reach a standard of living that was otherwise completely out of reach for an electrician living in the metropolis. He had a house, a car, some savings in the bank, and nothing more. I never remember anyone spending money in my house without a reason. We scrimped and saved. I believe that most of the colonists lived like my father, although they might have liked to flaunt their wealth when they went on vacation to the metropolis, which gave them a bad reputation, understandably. Those who went to Africa, went to work. You had to have a letter that guaranteed you a job. Then you had to wait a few more months to arrange for a boat. It was not easy. These colonists, like my father, built Lourenço Marques. Or rather, they made the blacks build their vision of a cosmopolitan city, under their command. It's not possible to speak of the colonists as mere perpetrators. That would be incorrect. I speak of my father, but I also knew his friends, the friends of our family. Mistreating blacks was not the goal. The goal was to put them to work, to civilize them, to take them out of their huts, in sum, to make black Europeans out of them, which would be a paradox for us, today, but wasn't for the men of my father's time. Later, it became apparent that there were colonists with fewer scruples. But that was not the case of my father, who saw himself as the father of his blacks.

IFG: Some readers have read Caderno de Memórias Coloniais as a book that can only represent a particular colonial experience and perspective, namely, that of the lower-class colonist. Do you see in this reading the possibility of making the presumptions and actions of colonialism disappear? How do you interpret the distinction some are making between the "good colonist" and the "bad colonist"?

IF: Of course there is a clear intent in this reading to hide the presumptions and actions of colonialism. There were 
colonists of all social classes, obviously. Society in Lourenço Marques had an upper class that was well represented. But to be a good colonist had nothing to do with the class to which one belonged but rather had to do with the type of person one is. Are members of the upper class necessarily better people than those of the lower class? It does not seem to be so today, just as it never was. There were good and bad colonists independent of the class to which they belonged. That's obvious. I should say that my father, despite the failings I attribute to him, was a good colonist. To me there is no difference in doing as my father did or having five servants that are paid poorly and treated with indifference. This all corresponds to a strategy of colonial power. What was different about my father? That he slapped his blacks? It's true, he hit them, in fact. But many other colonists in good standing verbally abused their blacks or sexually harassed or attacked them. And were these good colonists?

IFG: Caderno evokes and presents in a very powerful and raw manner the intimate side of colonialism, especially the sexuality of the Portuguese man, the paternal figure, the I, and of African and Portuguese women. What challenges did you face in writing about this aspect and in choosing the words to represent it? What did you try to show and what did you leave in the shadows?

IF: The narrative voice is mine. However, the linguistic register is not always mine. I use the words that the colonists used. For example, I write "preto" [black] whenever I am representing colonial discourse and "negro" [black] when I am expressing my own thoughts. I took some expressive liberties that are allowed me by its literariness. I do not remember ever hearing white women refer to the sexual organ of black women with a term as strong as what I used in the initial text. Nevertheless, without explicitly using this word, the white women referred to the sexuality of black women with contempt. I made use of the slang to express that vileness. I tried to incorporate in my discourse the violence of the feelings I experienced. I did not just throw 
words in there. There are things that I would not have been able to write in any other way.

IFG: What aspects of the convergence and clash between the Portuguese and Africans does Caderno try hardest to elucidate?

IF: Caderno does not try to elucidate anything. I don't want to take on that responsibility. I only want to tell a story, which happens to be mine. What I want most is for people to read the book like a literary work. That's all I can say.

IFG: The image of the colony as a concentration camp comes up several times in Caderno. One of the epigraphs cites The Drowned and the Saved by Primo Levi. Could you comment about the choice and effect of this epigraph as a key for reading the narrative?

IF: I greatly admire the work of Primo Levi. I admire his impartiality and consciousness that it is impossible to remember everything, and above all to remember the exact colors, though it is not possible to forget the pain. The memory of a traumatic experience is not a simple recollection. It involves pain, guilt, fear, reflection... In my case, it involves an intense psychoanalytic process. I felt the need to safeguard myself against the betrayal of memory. I mentioned above that I mix up some of the times and places. For example, I have in my head two scenes for the moment that someone informs my father that there has been a revolution in the metropolis, and I sincerely don't know which is real. As we recall events from the past, various lapses of this sort occur. As for the metaphor of the concentration camp: Lourenço Marques was a modern city, cosmopolitan, surrounded by neighborhoods of thatch huts and homes made from adobe. The whites lived in the city, and the blacks came to work there - they were concentrated from sun up to sun down. Primo Levi tells how prisoners would leave the concentration camp to work outside it. In Lourenço Marques, it was the opposite. The concentration camp was the place where one entered to work hard, and this work was a condemnation. 
IFG: Could you elaborate on the representation of the colonial family and home in Caderno de Memórias Coloniais and how the family can be interpreted as a symbol of Portuguese colonization?

IF: The old question of the family! The problem is that it didn't exist without the integration of the family, either in the colonies or in the metropolis. My mother married my father through an arrangement, she hardly knew him, and she went to Africa with him because it was unacceptable for a woman of her age at the time she married (36 years old) not to have resolved this aspect of her life. She did not marry for love but because the consequences of remaining single were damaging. She needed to be the wife of someone, because only the family gives status and provides for worthy social participation. Obviously, this same pattern was taken to the colony. For colonization depends on a network of families that support each other, that protect each other, that give work to innumerable indigenous people. The idea of the united and honest family is a model of life that was to be transmitted to the polygamous blacks.

IFG: If it were possible, would you like to meet the possible children that your father might have had in Africa, the mulatto heirs that you speak of in Caderno?

IF: I think about this often. I would like to, yes. I would like to meet these people who carry a mixture of my father's genes and the genes of the black race that was so castigated. It would be a very emotional meeting.

IFG: Although Caderno de Memórias Coloniais focuses on the Portuguese colonist in the figure of the father, women are visible and have an active role in colonization. Could you elaborate on the complex roles that Portuguese women played as members of a colonizing nation? In the specific case of the figure of the mother, what did the colonial experience mean to her? In what ways did the colonial context reinforce or alter the traditional roles of Portuguese women who went to Africa? 
IF: My mother is an exception. She was a traditional wife. But, generally speaking, colonial society was more permissive regarding what was considered fitting for a woman. Women worked freely outside the home, and this was not always a question of finances. Young women were encouraged to study and become educated so they could support themselves. This was a key issue for my father: so that I could have a good job and become independent. In colonial society, women did not spend a lot of time at home, even when they worked at home. That is, they accompanied their husbands, had social lives, went to cafés, restaurants, alone or accompanied. And once they were working alongside men - and I am recalling couples, who had canteens throughout the provinces abroad - they played an active part in the colonial structure and helped to maintain it. Women were largely spread out through the public services: banks, finances, records, and notaries. They remained subordinate, but much less so than in the metropolis, as I realized when I returned. Women in the colonies were a little freer, more emancipated. I think that this was related to the general environment of well-being that existed. The optimism and existential lightness in the colonies must have alleviated some of the tensions relating to gender.

IFG: In Caderno de Memórias Coloniais, the woman is the subject of self-representation. Could you comment if and in what ways your book dismantles the structure and culture of patriarchy and/or the autobiographical genre?

IF: Today there appears a woman who in 1975 was an adolescent and who assumes a voice that it simultaneously literary and documentary. It is an intrepid and irreverent voice, one that is socially and politically engaged. It comes with ideas. For the patriarchal structure, it's a little too much. Why didn't I stay quiet? Did it occur to me to think and write about that which patriarchy had no interest in thinking or writing about? Am I questioning myself about the world? Who do I think I am and can be? All of this dismantles in some way patriarchal structures, whether or not we admit it. Of course it does. 